\title{
THE FUNCTION OF THE Vi ANTIGEN OF SALMONELLA
} PARATYPHI A. COMPARISON BETWEEN VIRULENCE,
AGGLUTINABILITY BY ANTI-O IMMUNE SERA AND SEN-
SITIVITY TO THE BACTERICIDAL ACTION IN VITRO

\author{
BY A. L. OLITZKI, E. FLEISCHHACKER AND Z. OLITZKI \\ From the Department of Bacteriology, the Hebrew University-Hadassah \\ Medical School, Jerusalem, Israel
}

In earlier experiments of Felix \& Olitzki (1926) it was shown that the strain HA 1 of Salmonella paratyphi A which was highly sensitive to $O$ agglutinins was also highly susceptible to the bactericidal power of normal and immune rabbit serum, whereas the strain HA 6 was resistant to both. This observation was analogous to those on Salm. typhi, where lowered O agglutinability, resistance to bactericidal serum action, and virulence, were phenomena depending on the presence of an additional antigen $(\mathrm{Vi})$, which interfered with the reaction of the $\mathrm{O}$ antigen and its specific antibody (Felix \& Pitt, 1934a, $b$ ).

It was therefore expected that the same correlation between $O$ agglutinability, sensitivity to bactericidal action and virulence would also exist for Salm. paratyphi A, and experiments were carried out by Felix (1952) which revealed that this correlation between the presence of the Vi antigen and virulence is also true for this organism. On the other hand, Kauffmann \& Silberstein (1934) reported that the avirulent strain HA 1 did not contain the $O$ factor 1 , and Kauffmann (1953) claimed that no special ' Vi- antigen' of Salm. paratyphi A could be demonstrated. The $\mathrm{O}$ factor 2 was relatively unstable. Its agglutinable and agglutinin-binding properties were destroyed by $\mathrm{NaOH}$, whereas its antigenic properties were merely weakened.

The purpose of the present experiment was to find out whether there exists an antigen of Salm. paratyphi A which has same functions in vivo and in vitro as those described for the Vi antigen of Salm. typhi.

\section{MATERIALS AND METHODS}

Strains employed

The strains employed in these experiments were the classical strains HA 1 and HA 6 (kindly provided by the late Dr A. Felix) and a number of cultures isolated from sporadic cases of paratyphoid A, which occurred during 1953-4 in Israel. No epidemiological relationships were found between the different cases; the majority of them occurred in the urban population. Only two cases came from the same rural settlement (Givat Haim); they were isolated from two adult males. The first fell sick in December 1953, and the other 28 days later. The two strains, 2369 and 2455 , both belonged to phage type 1 , and were highly virulent. It is probable that there was a causative relationship between the two cases. This information was 
kindly provided by Dr F. Yacutiel, Department of Epidemiology, Ministry of Health. Most of the strains were forwarded for phage typing to Dr D. D. Banker in Bombay who identified nine out of twelve as belonging to the phage type 1 , and three as 'degraded, being tested further'.

Most of the strains were isolated from blood cultures. In the diagnostic laboratories they were transferred from the primary blood-bile culture to a lactose medium and after identification put up in agar stab cultures and sent to us. All these cultures comprised, therefore, at least the second subculture after primary isolation.

\section{Virulence tests}

Mice aged 4-5 weeks were employed.

The quantity of injected bacteria was determined photometrically and controlled by plating. A saline suspension was prepared which contained $8 \times 10^{8}$ bacteria $/ \mathrm{ml}$.; from this suspension $1 \cdot 0,0.5$ and $0.25 \mathrm{ml}$. were injected intra-abdominally. The results obtained with recently isolated strains as compared with the virulent strain HA 6 and the avirulent strain $\mathrm{HA} 1$ are presented in Table 1.

Table 1. Lethal effects in mice of fifteen recently isolated strains of Salmonella paratyphi $A$ compared with two standard strains

\begin{tabular}{cccc}
\multicolumn{4}{c}{ Deaths (groups of 8 mice) after infecting dose } \\
Standard strains: & & $4 \times 10^{8}$ & $2 \times 10^{8}$ \\
HA 1 & 3 & 0 & 0 \\
HA 6 & 8 & 6 & 1 \\
Recently isolated strains: & & \\
9137 & - & 5 & 3 \\
2503 & - & 7 & 1 \\
9205 & - & 7 & 2 \\
2518 & - & 7 & 1 \\
576 & - & 7 & 3 \\
2455 & - & 7 & 1 \\
Gall bladder & - & 7 & 2 \\
R54 54 & - & 6 & 1 \\
2369 & 8 & 5 & 3 \\
739 & 8 & 5 & 3 \\
607 & 8 & 5 & 0 \\
1745 & 8 & 3 & 0 \\
5893 & 8 & 3 & 0 \\
1265 & 5 & 2 & 0 \\
2124 & 4 & 1 & 0
\end{tabular}

This table shows that of fifteen recently isolated strains thirteen showed virulence similar to that of strain HA 6 and two were of lower virulence approaching that of HA 1 .

Experiments were undertaken in order to keep the recently isolated strains virulent. It was assumed (personal communication from the late Dr A. Felix) that traces of glucose in the medium would produce a slight acid reaction unfavour- 
able for the maintenance of virulence. To all three media tested, therefore, $\mathbf{0 . 2 5} \%$ of $\mathrm{Na}_{2} \mathrm{HPO}_{4}$ was added to keep the reaction slightly alkaline.

The composition of the three media employed (expressed in percentages) was:

\begin{tabular}{|c|c|}
\hline \multicolumn{2}{|l|}{ Medium A: } \\
\hline $\begin{array}{l}\text { Bacto peptone (Difco } \\
\text { standardized) }\end{array}$ & $1 \cdot 0$ \\
\hline Bovril (Bovril Ltd, London) & $0 \cdot 3$ \\
\hline $\mathrm{Na}_{2} \mathrm{HPO}_{4}$ & $0 \cdot 25$ \\
\hline $\mathrm{NaCl}$ & 0.5 \\
\hline Agar & $2 \cdot 5$ \\
\hline \multicolumn{2}{|l|}{$\mathrm{pH} 7 \cdot 4$} \\
\hline \multicolumn{2}{|l|}{ Medium B: } \\
\hline $\begin{array}{l}\text { Enzymatically digested casein } \\
\text { (N.B.C. Cleveland, Ohio) }\end{array}$ & $1 \cdot 0$ \\
\hline $\mathrm{Na}_{2} \mathrm{HPO}_{4}$ & 0.25 \\
\hline $\mathrm{NaCl}$ & $0 \cdot 5$ \\
\hline Agar & $2 \cdot 5$ \\
\hline \multicolumn{2}{|l|}{$\mathrm{pH} \mathbf{7 \cdot 4}$} \\
\hline \multicolumn{2}{|l|}{ Medium C: } \\
\hline Enzymatically digested casein & $1 \cdot 0$ \\
\hline $\mathrm{Na}_{2} \mathrm{HPO}_{4}$ & $0 \cdot 25$ \\
\hline $\mathrm{NaCl}$ & 0.5 \\
\hline $\begin{array}{c}\text { Gelatine (Difco standardized) } \\
\text { pH } \mathbf{7 \cdot 4}\end{array}$ & $2 \cdot 5$ \\
\hline
\end{tabular}

The virulence of all cultures was tested after keeping them for $2 \frac{1}{2}$ months in deep stab cultures; four selected virulent strains were tested after 9 months; they were also subcultured 15 times at 4-day intervals and their virulence again tested.

Table 2 shows the results of these experiments.

The cultures kept on the three media for $2 \frac{1}{2}$ months did not show significant differences in virulence. The respective number of deaths observed after infections with bacteria from media $\mathrm{A}, \mathrm{B}$ and $\mathrm{C}$ were 68,71 and 68 (actual numbers).

When the cultures were kept for 9 months on medium $\mathrm{C}$ a certain decrease of virulence was observed. The respective numbers of deaths observed after infection with bacteria from $\mathrm{A}, \mathrm{B}$ and $\mathrm{C}$ are 28,26 and 20 .

A similar observation was made after fifteen subcultures. The respective numbers observed after infections with bacteria from A, B and C are 30,32 and 22 .

It seems, therefore, that the media $\mathrm{A}$ and $\mathrm{B}$ are reliable for keeping Salm. paratyphi A virulent. It is noteworthy that strain 1265 , originally of low virulence, showed a gain in virulence on media $A$ and $B$.

\section{$H$ antigen}

\section{Agglutinating properties}

$\mathrm{H}$ antigens of the strains were prepared as follows:

Broth was inoculated from $20 \mathrm{hr}$. agar slants of the various cultures of Salm. paratyphi A. After $6 \mathrm{hr}$. incubation $0.5 \%$ formalin was added to the broth culture and the antigen kept overnight at $37^{\circ} \mathrm{C}$. The antigens were tested with a standard 
anti-H serum (titre with standard antigen $1: 20,000$ ) and results were read after incubation at $56^{\circ} \mathrm{C}$. for $2 \mathrm{hr}$.

From twelve recently isolated strains six proved to be $\mathrm{H}$ forms and six $\mathrm{O}$ forms.

Table 2. Lethal effects on mice of Salmonella paratyphi A kept on three different media by three different procedures. Infecting dose: $4 \times 10^{8}$ organisms (intraperitoneally)

proceedings:

No. 1. At room temperature $2 \frac{1}{2}$ months without subculturing.

No. 2. At room temperature 9 months without subculturing.

No. 3. Fifteen subcultures made in 4-day intervals.

\begin{tabular}{|c|c|c|c|c|c|}
\hline & & Deat & serv & roups & 8 mice \\
\hline & & By & $\mathrm{ms}$ & nedia & By the \\
\hline Procedure & Strains & A & $\mathrm{B}$ & C & strain \\
\hline No. 1 (kept $2 \frac{1}{2}$ months) & HA 1 & 0 & 0 & 0 & 0 \\
\hline & $\mathrm{HA} 6$ & 7 & 5 & 7 & 6 \\
\hline & 2369 & 5 & 8 & 6 & 8 \\
\hline & 5893 & 7 & 3 & 7 & 3 \\
\hline & 1265 & $\bar{j}$ & 5 & 2 & 2 \\
\hline & $R . j 4$ & 6 & 4 & i; & 6 \\
\hline & 607 & 5 & 7 & i & 5 \\
\hline & 576 & $T$ & 7 &.$\overline{3}$ & 7 \\
\hline & 2.50 .3 & 6 & $\overline{7}$ & $\bar{j}$ & 7 \\
\hline & $245 \overline{5}$ & 7 & $s$ & $x$ & 7 \\
\hline & 2518 & 5 & 7 & $i$ & 7 \\
\hline & 9137 & 4 & $\tilde{j}$ & 3 & 5 \\
\hline & $920 . \overline{3}$ & 4 & 5 & 6 & 7 \\
\hline & Totals & 68 & 71 & 158 & 70 \\
\hline No. 2 (kept 9 months) & 2369 & 5 & 5 & 6 & 7 \\
\hline & 576 & 7 & 7 & 6 & 8 \\
\hline & 2518 & 8 & 6 & 3 & 7 \\
\hline & 24.55 & $x$ & 8 & 5 & 8 \\
\hline & Totals & 28 & 26 & 20 & 30 \\
\hline No. 3 (15 subcultures) & 2369 & 7 & 8 & 5 & 8 \\
\hline & 576 & 7 & 8 & 6 & 7 \\
\hline & 2518 & 8 & 8 & 5 & 7 \\
\hline & 245.5 & 8 & 8 & 6 & 7 \\
\hline & Totals & 30 & 32 & 22 & 29 \\
\hline
\end{tabular}

\section{$O$ antigen}

Saline suspensions of living bacteria from $24 \mathrm{hr}$. agar slants were used. The agglutination tubes were incubated at $37^{\circ} \mathrm{C}$. for $2 \mathrm{hr}$. and kept overnight in the cold room. The antiserum was prepared with alkali-treated bacteria of strain 2369. All freshly isolated bacteria were of the $\mathrm{S}$ type and yielded stable suspensions in $5 \cdot 0,2 \cdot 5$ and $0 \cdot 85 \%$ saline, whether living or boiled.

The avirulent strain HA $\mathrm{H}$ was agglutinated by the $\mathrm{O}$ serum up to a dilution of $1: 5000$, the virulent strain HA 6 up to $1: 500$. From fifteen recently isolated strains seven were agglutinated up to $1: 1000$ and eight up to $1: 2000$. None reached the titre $1: 5000$ of the avirulent HA 1 . 


\section{A Vi antigen}

A paratyphoid A Vi serum (A Vi) was kindly provided by the late Dr A. Felix. This serum had been prepared by immunization of a rabbit with strain A 2035 exposed to $0.2 \%$ formalin and absorption of the $\mathrm{O}$ antibodies with strain A 17689 exposed to $0 \cdot 05 \mathrm{~N}-\mathrm{NaOH}$. Living suspensions of all recently isolated strains were agglutinated by this serum to titres of $1: 200-1: 1000$ (Table 3).

Table 3. Agglutination of living Salmonella paratyphi $A$ by $A$ Vi antiserum

$\begin{array}{cc}\text { Strain } & \begin{array}{c}\text { Titre of } \\ \text { agglutination }\end{array} \\ \text { HA1 } 1 & 1: 2000 \\ \text { HA } 6 & 1: 500 \\ 2035 & 1: 500 \\ 17689 & 1: 2000 \\ \text { isolated strains } & \\ \text { m. parat.yphi A } & 1: 1000 \\ 1(2369) & 1: 500 \\ 7 & 1: 200 \\ 5 & \end{array}$

\section{Bactericidal action of normal and immune sera}

The following experiments were carried out according to the technique of Felix \& Olitzki (1926). Inocula of about 5000 bacteria were employed which, in the presence of inactivated serum, multiplied to about 40,000 within $3 \mathrm{hr}$, i.e. about three cell divisions had taken place. Table 4 shows the sensitivity of nine different strains to the bactericidal action of normal rabbit serum. The virulent strains

Table 4. Bactericidal action of normal rabbit serum on virulent and non-virulent strains (dose $4 \times 10^{8}$ ) of Salmonella paratyphi $A$, compared with their agglutinability in $O$ antiserum

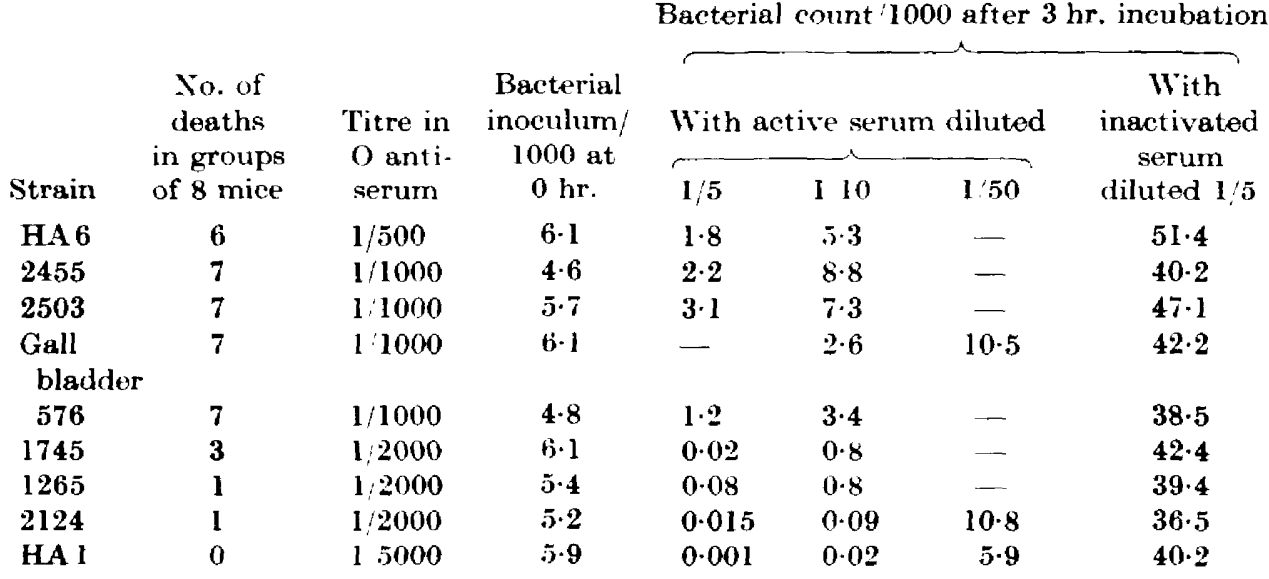

killed seven of eight mice when injected intraperitoneally in quantities of $4 \times 10^{8}$; they were less reactive to $O$ antibodies (titre $1: 500-1: 1000$ ), and the active normal serum at a 1:5 dilution reduced the bacterial count within $3 \mathrm{hr}$. to at least $50 \%$ of 
the initial inoculum. On the other hand, the avirulent strains were more sensitive to $\mathrm{O}$ antibodies (titres $1: 2000-1: 5000$ ), and normal active rabbit serum diluted $1: 5$ reduced their number to less than $1 \%$ of the initial inoculum. Serum diluted 1:10 exerted a marked bactericidal effect on the avirulent strains but did not significantly reduce the number of virulent bacteria.

Table 5. The bactericidal action of $O$ antiserum*, with added normal rabbit serum diluted 1:50 as complement, on virulent and non-virulent strains (test dose: $4 \times 10^{8}$ intraperitoneally) of Salmonella paratyphi $A$, compared with their agglutinability by anti-O serum

\begin{tabular}{|c|c|c|c|c|c|c|c|c|}
\hline \multirow[b]{3}{*}{ Strain } & \multirow{3}{*}{$\begin{array}{l}\text { No. of } \\
\text { deaths in } \\
\text { groups of } \\
8 \text { mice }\end{array}$} & \multirow[b]{2}{*}{$\begin{array}{l}\text { Reciprocal } \\
\text { of I } \\
\text { O aggluti. }\end{array}$} & \multicolumn{6}{|c|}{ Bacterial count/ 1000 after $3 \mathrm{hr}$. incubation } \\
\hline & & & Inoculum/ & $\begin{array}{r}\text { With } \\
\text { O an }\end{array}$ & tiserum & $\begin{array}{l}\text { dent and } \\
\text { diluted }\end{array}$ & $\begin{array}{c}\text { Comple- } \\
\text { ment } \\
\text { active } \\
\text { without } \\
\text { anti- }\end{array}$ & Complement \\
\hline & & nation titre & $0 \mathrm{hr}$. & $1 / 100$ & $1 / 1000$ & $1 / 10000$ & serum & inactivated \\
\hline HA 1 & $\mathbf{0}$ & 5000 & $6 \cdot 2$ & $0 \cdot 02$ & $0 \cdot 06$ & $0 \cdot 1$ & $3 \cdot 7$ & $40 \cdot 2$ \\
\hline 2124 & 1 & 2000 & $5 \cdot 6$ & $2 \cdot 7$ & $3 \cdot 1$ & $0 \cdot 1$ & $15 \cdot 4$ & $37 \cdot 4$ \\
\hline 1745 & 3 & 2000 & $6 \cdot 4$ & $5 \cdot 2$ & $7 \cdot 6$ & $8 \cdot 4$ & $12 \cdot 5$ & $35 \cdot 4$ \\
\hline 2455 & 7 & 1000 & $5 \cdot 8$ & $4 \cdot 6$ & $13 \cdot 5$ & $7 \cdot 4$ & $44 \cdot 5$ & 55.0 \\
\hline $\begin{array}{l}\text { Gall } \\
\text { bladder }\end{array}$ & 7 & 1000 & $6 \cdot 3$ & $5 \cdot 0$ & $12 \cdot 0$ & $11 \cdot 9$ & $41 \cdot 4$ & $45 \cdot 3$ \\
\hline 2503 & 7 & 1000 & $6 \cdot 1$ & $4 \cdot 7$ & $10 \cdot 1$ & $12 \cdot 0$ & $30 \cdot 0$ & $42 \cdot 0$ \\
\hline HA 6 & 6 & 500 & $7 \cdot 2$ & $7 \cdot 3$ & $18 \cdot 8$ & $8 \cdot 4$ & $12 \cdot 5$ & $35 \cdot 4$ \\
\hline
\end{tabular}

Table 5 shows the bactericidal effect of an $\mathrm{O}$ antiserum produced with alkalitreated bacteria of strain 2369. Normal active rabbit serum was employed as complement which, in a dilution 1:50, was not bactericidal and even permitted slight multiplication of the virulent strains. Even with this low dilution of complement the $O$ serum exerted a marked bactericidal effect on the virulent strains HA 1 and 2124.

In the following experiments, therefore, only the virulent strain 2455 was used, as it was not sensitive to the action of normal rabbit serum (complement). Table 6 shows the bactericidal effect of seven immune sera containing varying concentrations of $\mathrm{O}$ and $\mathrm{A} \mathrm{Vi}$ agglutinin. The most powerful bactericidal action was exerted by serum $812 / 3$, which, even in a dilution of $1: 100,000$ with a complement concentration of $1: 20$, destroyed over $99 \%$ of the bacterial inoculum.

None of three anti-O sera of similar titre which did not contain A Vi antibody, showed a comparable bactericidal effect. One of them (1211/2) acted at a dilution $1: 10,000$, another $(1214 / 2)$ at $1: 1000$ and a third $(1207 / 2)$ gave a marked complement deviation at $1: 100$ (Neisser-Wechsberg phenomenon) and acted strongly at dilution $1: 1000$ and 1:10,000; however, at $1: 100,000$ over $10 \%$ of the bacterial inoculum survived.

Serum $808 / 4$ which contained $O$ antibody as $813 / 3$ but less A Vi antibody acted strongly at a dilution of $1: 10,000$. 
Table 6. The bactericidal power of different types of Salmonella paratyphi $A$ immune sera against the virulent strain $\mathbf{2 4 5 5}$

\begin{tabular}{|c|c|c|c|c|c|c|c|}
\hline \multirow[b]{2}{*}{ No. } & \multirow[b]{2}{*}{$\begin{array}{l}\text { Antigen used for } \\
\text { immunization }\end{array}$} & \multicolumn{2}{|c|}{ Agglutinin titre } & \multirow[b]{2}{*}{ Dilution } & \multirow{2}{*}{$\begin{array}{l}\text { Time of } \\
\text { exposure }\end{array}$} & \multicolumn{2}{|c|}{$\begin{array}{c}\text { Bacterial } \\
\text { count/1000 } \\
\text { with } \\
\text { complement }\end{array}$} \\
\hline & & $0^{*}$ & $\widehat{A V i}$ & & & $1: 50$ & $1: 20$ \\
\hline $808 / 4$ & A 2035, $75_{0}^{\circ}$ alcohol & 10,000 & 800 & $\begin{array}{l}1: 10^{2} \\
1: 10^{3} \\
1: 10^{4} \\
1: 10^{5}\end{array}$ & $\begin{array}{l}3 \\
3 \\
3 \\
3\end{array}$ & $\begin{array}{c}14 \cdot 6 \\
2 \cdot 3 \\
0 \cdot 06 \\
3 \cdot 3\end{array}$ & $\begin{array}{l}0 \cdot 28 \\
0 \cdot 08 \\
0 \cdot 22 \\
6 \cdot 1\end{array}$ \\
\hline $812 / 3$ & A 2035, $0 \cdot 2 \%$ formalin & 10,000 & 2000 & $\begin{array}{l}1: 10^{2} \\
1: 10^{3} \\
1: 10^{4} \\
1: 10^{5}\end{array}$ & $\begin{array}{l}3 \\
3 \\
3 \\
3\end{array}$ & $\begin{array}{r}18 \cdot 1 \\
12 \cdot 5 \\
4 \cdot 7 \\
3 \cdot 3\end{array}$ & $\begin{array}{l}5 \cdot 8 \\
0 \cdot 28 \\
0 \cdot 07 \\
0 \cdot 10\end{array}$ \\
\hline $829 / 3$ & $\mathrm{HA} 6, \mathrm{~N}-\mathrm{HCl} 37^{\circ} \mathrm{C}$ & 5,000 & 50 & $\begin{array}{l}1: 10^{2} \\
1: 10^{3} \\
1: 10^{4} \\
1: 10^{5}\end{array}$ & $\begin{array}{l}3 \\
3 \\
3 \\
3\end{array}$ & $\begin{array}{c}16 \cdot 3 \\
1 \cdot 8 \\
0 \cdot 14 \\
0 \cdot 16\end{array}$ & $\begin{array}{l}0.01 \\
0.02 \\
0.08 \\
0.40\end{array}$ \\
\hline $1207 ; 2$ & $\begin{array}{l}\mathrm{A} 2035,0 \cdot 05 \mathrm{~N} \cdot \mathrm{NaOH} \\
4 \mathrm{hr} \text {. room temperature }\end{array}$ & 20,000 & 0 & $\begin{array}{l}1: 10^{2} \\
1: 10^{3} \\
1: 10^{4} \\
1: 10^{5}\end{array}$ & $\begin{array}{l}3 \\
3 \\
3 \\
3\end{array}$ & $\begin{array}{r}24 \cdot 5 \\
6 \cdot 5 \\
1 \cdot 6 \\
11 \cdot 3\end{array}$ & $\begin{array}{l}8 \cdot 0 \\
0 \cdot 01 \\
0 \cdot 1 \\
6 \cdot 2\end{array}$ \\
\hline $1211 / 2$ & $\begin{array}{l}\text { A } 2035,0.05 \mathrm{~N} \cdot \mathrm{NaOH} \\
4 \mathrm{hr} \text {. room temperature }\end{array}$ & 10,000 & 0 & $\begin{array}{l}1: 10^{2} \\
1: 10^{3} \\
1: 10^{4} \\
1: 10^{5}\end{array}$ & $\begin{array}{l}3 \\
3 \\
3 \\
3\end{array}$ & $\begin{array}{r}2 \cdot 4 \\
2 \cdot 3 \\
2 \cdot 8 \\
26 \cdot 2\end{array}$ & $\begin{array}{r}0 \cdot 4 \\
0 \cdot 2 \\
0 \cdot 2 \\
22 \cdot 0\end{array}$ \\
\hline $1214 / 2$ & $\mathrm{HA} 1,2 \frac{1}{2}$ hr. at $100^{\circ} \mathrm{C}$. & 2,000 & 0 & $\begin{array}{l}1: 10^{2} \\
1: 10^{3} \\
1: 10^{4} \\
1: 10^{5}\end{array}$ & $\begin{array}{l}\mathbf{3} \\
\mathbf{3} \\
\mathbf{3} \\
\mathbf{3}\end{array}$ & $\begin{array}{r}1 \cdot 8 \\
2 \cdot 3 \\
5 \cdot 6 \\
60 \cdot 0\end{array}$ & $\begin{array}{r}0 \cdot 3 \\
0 \cdot 3 \\
17 \cdot 0 \\
60 \cdot 0\end{array}$ \\
\hline 8123 & $\begin{array}{l}\text { A } 2035,0 \cdot 2^{\circ} \text { o formalin } \\
\text { absorbed with A } 17689 \\
\times-\mathrm{NaOH}\end{array}$ & 0 & 2000 & $\begin{array}{l}1: 10^{3} \\
1: 10^{4} \\
1: 10^{5}\end{array}$ & $\begin{array}{l}3 \\
3 \\
3\end{array}$ & $\begin{array}{l}10 \cdot 8 \\
20 \cdot 5 \\
60 \cdot 0\end{array}$ & $\begin{array}{r}9 \cdot 6 \\
4 \cdot 2 \\
35 \cdot 0\end{array}$ \\
\hline Control & without serum & & & & $\begin{array}{l}0 \\
3 \\
3\end{array}$ & $\begin{array}{l}43 \cdot 0 \\
160 \cdot 0 \\
250 \cdot 0_{+}^{+}\end{array}$ & $\begin{array}{c}46 \cdot 0 \\
55 \cdot 0 \\
300 \cdot 0 \ddagger\end{array}$ \\
\hline
\end{tabular}

Serum $812 / 3$ absorbed with $\mathrm{N}-\mathrm{NaOH}$-treated bacteria and containing $\mathrm{A} \mathrm{Vi}$ antibody exerted only a weak bactericidal effect; it acted only up to $1: 10,000$ and destroyed $90 \%$ of the bacterial inoculum.

Conditions which produce a maximal bactericidal action by the combined effect of $\mathrm{AVi}$ and $\mathrm{AO}$ antibodies were examined.

Table 7 shows that in order to exert such a maximal effect with more than a $99 \%$ kill an optimal proportion between the concentration of the two antibodies is necessary.

Part 1 and part 4 of Table 7 show that Vi and $O$ antibodies separately do not exert this maximal effect : in parts 2 and 3 where the $\mathrm{A} \mathrm{Vi}$ antibody was present in 
relatively high concentrations the maximal bactericidal effect was not reached; it seems even that the bactericidal action of the $O$ antibody is markedly weakened as compared with part 1 when the $\mathrm{O}$ antibody acted alone.

Table 7. The combined bactericidal effect of $O$ and $V i$ serum on a virulent strain of Salmonella paratyphi $A$ (2455). Two experiments with complement 1:50 and $1: 20$

\begin{tabular}{|c|c|c|c|c|c|}
\hline \multirow{3}{*}{ Part 1} & \multicolumn{2}{|c|}{ Bacterial inoculum exposed to } & \multirow{2}{*}{$\begin{array}{l}\text { Time } \\
\text { (hr.) }\end{array}$} & \multicolumn{2}{|c|}{$\begin{array}{c}\text { Bacterial count } 1000 \\
\text { with complement }\end{array}$} \\
\hline & Vi serum* & O serum $†$ & & $1: 50$ & $1: 20$ \\
\hline & $\begin{array}{l}- \\
- \\
-\end{array}$ & $\begin{array}{l}1: 10^{2} \\
1: 10^{3} \\
1: 10^{4} \\
1: 10^{5}\end{array}$ & $\begin{array}{l}3 \\
3 \\
3 \\
3\end{array}$ & $\begin{array}{r}1 \cdot 7 \\
3 \cdot 6 \\
11 \cdot 6 \\
50 \cdot 4\end{array}$ & $\begin{array}{r}0 \cdot 9 \\
6 \cdot 1 \\
28 \cdot 2 \\
70 \cdot 0\end{array}$ \\
\hline Part 2 & $\begin{array}{l}1: 2 \times 10^{2} \\
1: 2 \times 10^{3} \\
1: 2 \times 10^{4}\end{array}$ & $\begin{array}{l}1: 10^{3} \\
1: 10^{4} \\
1: 10^{5}\end{array}$ & $\begin{array}{l}3 \\
3 \\
3\end{array}$ & $\begin{array}{l}14 \cdot 0 \\
28 \cdot 2 \\
36 \cdot 7\end{array}$ & $\begin{array}{l}12 \cdot 9 \\
31 \cdot 6 \\
80 \cdot 0\end{array}$ \\
\hline Part 3 & $\begin{array}{l}1: 5 \times 10^{2} \\
1: 5 \times 10^{2} \\
1: 5 \times 10^{2} \\
1: 5 \times 10^{2} \\
1: 5 \times 10^{2}\end{array}$ & $\begin{array}{l}1: 10^{2} \\
1: 10^{3} \\
1: 10^{4} \\
1: 10^{5} \\
1: 10^{9}\end{array}$ & $\begin{array}{l}3 \\
3 \\
3 \\
3 \\
3\end{array}$ & $\begin{array}{l}17 \cdot 4 \\
16 \cdot 7 \\
18 \cdot 6 \\
18 \cdot 0 \\
19 \cdot 8\end{array}$ & $\begin{array}{l}21 \cdot 0 \\
15 \cdot 7 \\
15 \cdot 6 \\
27 \cdot 6 \\
40 \cdot 6\end{array}$ \\
\hline Part 4 & $\begin{array}{l}1: 2 \times 10^{2} \\
1: 5 \times 10^{2} \\
1: 2 \times 10^{3} \\
1: 2 \times 10^{4}\end{array}$ & - & $\begin{array}{l}3 \\
3 \\
3 \\
3\end{array}$ & $\begin{array}{r}8 \cdot 4 \\
18 \cdot 4 \\
19 \cdot 3 \\
22 \cdot 0\end{array}$ & $\begin{array}{l}11 \cdot 6 \\
20 \cdot 8 \\
30 \cdot 4 \\
40 \cdot 3\end{array}$ \\
\hline Part 5 & $\begin{array}{l}1: 2 \times 10^{2} \\
1: 2 \times 10^{3} \\
1: 2 \times 10^{4}\end{array}$ & $\begin{array}{l}1: 5 \times 10^{2} \\
1: 5 \times 10^{2} \\
1: 5 \times 10^{2}\end{array}$ & $\begin{array}{l}3 \\
3 \\
3\end{array}$ & $\begin{array}{r}9 \cdot 6 \\
11 \cdot 6 \\
6 \cdot 7\end{array}$ & $\begin{array}{r}17 \cdot 0 \\
8 \cdot 7 \\
0 \cdot 8\end{array}$ \\
\hline Part 6 & $\begin{array}{l}1: 5 \times 10^{3} \\
1: 1 \times 10^{4} \\
1: 2 \times 10^{4} \\
1: 5 \times 10^{4} \\
1: 1 \times 10^{5}\end{array}$ & $\begin{array}{l}1: 1 \times 10^{2} \\
1: 2 \times 10^{2} \\
1: 5 \times 10^{2} \\
1: 1 \times 10^{3} \\
1: 2 \times 10^{3}\end{array}$ & $\begin{array}{l}\mathbf{3} \\
\mathbf{3} \\
\mathbf{3} \\
\mathbf{3} \\
\mathbf{3}\end{array}$ & $\begin{array}{r}11 \cdot 7 \\
10 \cdot 8 \\
5 \cdot 5 \\
11 \cdot 9 \\
7 \cdot 9\end{array}$ & $\begin{array}{l}0 \cdot 20 \\
0 \cdot 07 \\
0 \cdot 18 \\
0 \cdot 08 \\
6 \cdot 2\end{array}$ \\
\hline Part 7 & - & - & $\begin{array}{l}0 \\
3 \\
3\end{array}$ & $\begin{array}{c}17 \cdot 8 \\
52 \cdot 6 \\
100 \cdot 0_{+}^{+}\end{array}$ & $\begin{array}{c}24 \cdot 8 \\
80 \cdot 0 \\
200 \cdot 0+\end{array}$ \\
\hline
\end{tabular}

* Vi serum (812/3): rabbits immunized with HA 2035 $0.2 \%$ formalin; serum absorbed with A $17689,0.05 \mathrm{~N} \cdot \mathrm{NaOH}$.

$\dagger$ O serum (1215/3): rabbits immunized with $\mathrm{HA} 1,2 \frac{1}{2} \mathrm{hr}$. at $100^{\circ} \mathrm{C}$.

$\ddagger$ Complement-inactivated.

Part 5 of Table 7 shows that a maximal bactericidal action was reached at a dilution of $\mathrm{AO}$ antiserum $1: 500$ and a dilution of the $\mathrm{AVi}$ antiserum $1: 20,000$, i.e. a 40 times higher concentration of the $O$ antiserum. A proportion of $50: 1$ between the $\mathrm{O}$ and the $\mathrm{Vi}$ titres was employed in the experiments summarized in part 6 of the same table and seems to be the most suitable.

Since the $O$ titre of the $O$ serum was $1: 20,000$ and the Vi titre of the Vi sera measured by living A 17689 was 1:2000, this proportion means that the optimal 
bactericidal effect is reached when the proportion of the minimal agglutinating units for $\mathrm{O}$ and $\mathrm{Vi}$ antibodies is $500: 1$.

In this connexion it is interesting to note that in the experiment summarized in Table 6 the most powerful bactericidal action at both complement dilutions is possessed by serum $829 / 3$, where the proportion of minimal agglutinating units $\mathrm{AO}: \mathrm{AVi}$ is $100: 1$, and not by the sera $808: 4$ and $812 / 3$, where the proportions are $12: 1$ and $5: 1$ respectively.

\section{Sublethal infections of mice}

In order to determine the spread of the infection by virulent and non-virulent micro-organisms in different organs, groups of mice were inoculated with strains of both types. The animals were sacrificed and the organs cultured in broth and on the surface of plates of McConkey's medium.

The infecting dose for the avirulent strain HAl was $2 \times 10^{8}$, for the virulent strains $1 \times 10^{8}$.

The results obtained with this method were as follows:

Until the third day after the onset of infection all the organs tested (heart, liver and spleen) were positive, independently of the virulence of the infecting strain. On the 7 th day the hearts of three mice infected with HA I were sterile, while the infection persisted in the spleen and liver.

A similar result was obtained with the same strain in mice on the 10 th day after the infection. From the 14 th to the $23 \mathrm{rd}$ day only $50 \%$ of mice were still infected with HA 1, and then only in the liver and spleen, never in the heart.

On the other hand, the virulent strain persisted longer in the heart blood. The first sterile culture appeared on the 18th day, and from the 23rd day all heart cultures were sterile.

The virulent strains which persisted after the 7th day and until the 18th day were: HA 6, Rp. 54, 2455 and 2369.

Since this method did not reveal quantitative differences between infection with virulent and non-virulent strains, quantitative determinations were carried

Table 8. Bacterial counts in organs of mice (average of five animals) after infection with virulent and avirulent bacteria

Bacterial count after infection with strain

\begin{tabular}{|c|c|c|c|c|c|c|}
\hline \multirow{2}{*}{$\begin{array}{l}\text { Day after } \\
\text { infection }\end{array}$} & \multicolumn{3}{|c|}{9205 (virulent) in } & \multicolumn{3}{|c|}{ HA I (avirulent) in } \\
\hline & Heart & Liver & Spleen & Heart & Liver & Spleen \\
\hline 1 & $2 \times 10^{4}$ & $3.2 \times 10^{6}$ & $4 \times 10^{6}$ & $1 \times 10^{4}$ & $4 \times 10^{4}$ & $3 \times 10^{4}$ \\
\hline 2 & $7 \times 10^{2}$ & $8 \times 10^{5}$ & $1.2 \times 10^{5}$ & $1 \times 10^{2}$ & $4 \times 10^{3}$ & $2.7 \times 10^{3}$ \\
\hline 3 & $2 \times 10^{2}$ & $1.7 \times 10^{5}$ & $1.8 \times 10^{4}$ & $1 \times 10^{2}$ & $1.9 \times 10^{3}$ & $2.6 \times 10^{3}$ \\
\hline 5 & $1 \times 10^{2}$ & $7.5 \times 10^{3}$ & $9 \times 10^{3}$ & $1 \times 10^{2}$ & $2 \cdot 1 \times 10^{3}$ & $9 \times 10^{2}$ \\
\hline 9 & $2 \times 10^{2}$ & $1.8 \times 10^{3}$ & $3.4 \times 10^{3}$ & $1 \times 10^{2}$ & $1 \times 10^{3}$ & $5 \times 10^{2}$ \\
\hline 14 & $2 \times 10^{2}$ & $2.2 \times 10^{3}$ & $10^{3}$ & 10 & $2 \times 10^{2}$ & $10^{2}$ \\
\hline 17 & 10 & $2 \times 10^{2}$ & $10^{2}$ & 10 & 10 & $10^{2}$ \\
\hline 22 & $10^{2}$ & $10^{2}$ & $4 \times 10^{2}$ & 10 & $10^{2}$ & $10^{2}$ \\
\hline 31 & $\mathbf{0}$ & 10 & 10 & 10 & 10 & 10 \\
\hline 45 & 0 & 0 & 0 & 0 & $\mathbf{0}$ & $\mathbf{0}$ \\
\hline
\end{tabular}


out of the number of bacteria in spleen and liver according to the method described by Olitzki \& Sulitzeanu (1954) for Brucellae, where the organs of five mice together were triturated and cultured after suitable dilution. An experiment is summarized in Table 8. During the first $\mathbf{1 4}$ days there were generally higher bacterial counts in the organs infected with virulent strains. Later the number became more or less equal, and no quantitative differences between the two strains were observed.

The virulence of residual bacteria after 30-40 days was tested, on the supposition that these surviving bacteria would be of high virulence. This assumption was not confirmed by experiment; the survivors of the HA 1 bacteria remaining avirulent even after they had persisted 30-40 days in the organs.

\section{DISCLESION}

The experiments described show that an antigen exists in virulent Salm. paratyphi A which exerts all the functions of the Vi antigen of salm. typhi. It interferes with the agglutinability of the bacteria by anti-O serum and inhibits the bactericidal action of anti-O serum together with complement.

The antibody produced by this antigen had no bactericidal effect on the avirulent strain HA 1, which Felix (1952) showed to possess only small amounts of the antigen and which is highly sensitive to anti-O serum as well as to normal rabbit serum alone. On the other hand, the anti-Vi immune serum prepared by absorption with $\mathrm{NaOH}$-treated bacteria enhanced the relatively weak bactericidal action of anti-O serum on such virulent organisms as strain 2455 . This antigen was present in the majority of recently isolated strains of salm. paratyphi A.

If Kauffmann (1953) is correct that the only difference between the avirulent strain HA 1 and virulent Salm. paratyphi A strains is the lack of $O$ factor 1 , then it is difficult to understand why a serum prepared with a formalin-treated antigen of strain HA 2035, after absorption with $\mathrm{NaOH}$-treated A 17689, still agglutinated strain HA 1. Since the agglutinin-binding capacity of factor 2 is, according to Kauffmann, destroyed by $\mathrm{NaOH}$ this procedure should remove antiborlies against factors 1 and 12 and leave only antibodies against factor 2 .

The assumption of Felix (1952) that there exists in addition a $\mathrm{Vi}$ antigen which determines the virulence of Salm. paratyphi A strains is in stricter accord with the present experimental data.

An anti- $\mathrm{V}_{\mathrm{i}}$ serum enhanced markedly the bactericidal action of an $\mathrm{O}$ serum. The anti-O serum was prepared with strain $\mathrm{HAl}$ heated for $2 \frac{1}{2} \mathrm{hr}$. at $100^{\circ} \mathrm{C}$. According to Kauffmann (1953) as well as Felix (1952) this should contain anti-2 and anti-12 antibodies.

The Vi-serum was prepared with formalinized strain HA 2035 which contains the factors 1, 2 and 12. It was absorbed with $\mathrm{NaOH}$-treated strain $\mathrm{A} 17689$ which after this treatment would still be capable of binding antibodies against the factors 1 and 12. Therefore, after absorption, the serum would contain (according to Kauffmann) the antibody against factor 2, since the binding capacity of this antibody was destroyed by $\mathrm{NaOH}$ in the absorbing antigen. 
The marked bactericidal effects of the combined application of these two sera should, therefore, result from enhancement of the anti-2 factor. This assumption, however, is untenable if we take into account that the anti-Vi serum (Felix) or anti-2 serum (Kauffmann) still acts in high dilutions in combination with an anti$2+12$ serum, although itself alone it is almost inactive. If we take into account the combined effects of anti-O and anti-Vi sera on Salm.typhi, then the explanation of Felix (1952) that there exists a Vi antibody is more plausible.

However, the main difference between the function of the $\mathrm{A} \mathrm{Vi}$ and $\mathrm{T} \mathrm{Vi}$ antigen in the bactericidal action of antisera seems to be the fact that among the strains of Salm. paratyphi A there do not exist the extreme $O$ forms completely lacking the $\mathrm{Vi}$ antigen and extreme $\mathrm{V} i$ forms which are completely inagglutinable by anti$\mathrm{O}$ serum. Even the non-virulent strain HAl still contains AVi antigen, and the most virulent recently isolated strains are agglutinable to some extent in anti$O$ serum. An optimal proportion between these two antibodies is necessary in order to exert a maximal bactericidal effect in the presence of complement. Highly virulent strains produced a higher bacterial count in liver and spleen in infected mice when doses of $10^{8}$ organisms were given intra-abdominally.

\section{SUMMARY}

Experiments were performed which show that virulent strains of Salmonella para. typhi A contain an additional antigen which has all the properties of a Vi antigen.

The anti- $\mathrm{Yi}$ immune serum combined in suitable proportions with an anti-O immune serum exerted maximal bactericidal effect on virulent strains.

The authors recall with gratitude the great help afforded them by the late Dr Arthur Felix by his constant advice, his suggestions for experiments and provision of immune sera and strains.

\section{REFERENCES}

Felix, A. (1952). J. Hyg., Camb., 50, 540.

Felix, A. \& Olitzki, A. L. (1926). J. Immunol. 11, 31.

Felix, A. \& Pitt, R. M. (1934a). J. Path. Bact. 38, 401.

Felix, A. \& PITT, R. M. (1934b). Lancet, 2, 186.

Feltx, A. \& PITT, R. M. (1936). Brit. J. exp. Path. 17, 81.

KatfrMax, F. (1941). Die Bakteriologie der Salmonella-Gruppe. Kopenhagen: Einar Munksgaard.

Kacffmaxx, F. (1953). Acta path, microbiol. Scand, 32, 574.

Kadfriana. F. \& Silbensteis, W. (1934). Zbl. Bakt. Abt. i, Orig. 132, 431.

Olitzki, A. L. \& Sulrtzense, D. (1954). J. infect. Dis. 94, 213.

(MS. received for publication 23. viI. 56) 